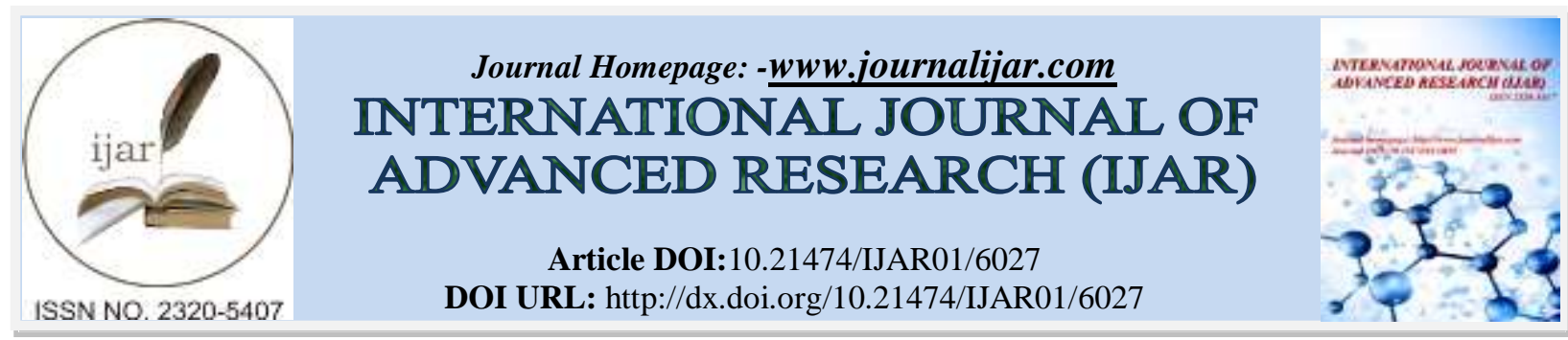

RESEARCH ARTICLE

\title{
ANTIDIABETIC POTENCY OF LEAVES OF AJUGA BRACTEOSA ON HYPOGLYCEMIC ACTIVITY IN ALLOXAN INDUCED DIABETIC CHICKS.
}

Dharmendra Kumar and RekhaBisht.

Department of Zoology, S. V. Govt. P. G. College, Lohaghat -262524, Champawat, Uttarakhand.

\section{Manuscript Info}

Manuscript History

Received: 11 October 2017

Final Accepted: 13 November 2017

Published: December 2017

Key words:-

Diabetes mellitus, Hypoglycemic, Hydroalcoholic extract, Ajugabracteosa, Alloxan.

\section{Abstract}

The hydroalcoholic extract of leaves of Ajuga bracteosa (Ratpatiya) at the rate of $10 \mathrm{mg} / 100 \mathrm{gm}$ body weight was tested as antidiabetic for hypoglycemic activity in alloxan induced diabetic chicks. Alloxan was used to induce diabetes mellitus in chicks and the blood glucose level were estimated by using commercial kit (Span Biotech, Surat, India). After the confirmation of diabetes in chicks, hydroalcoholic extract of leaves of Ajuga bracteosa was administered orally to the diabetic chicks for 30 days daily. The present investigation revealed that a significant reduction of blood glucose levels was observed in diabetic chicks treated with leaves of Ajuga bracteosa as an antidiabetic therapy, although the blood glucose level was observed higher in diabetic control chicks $(\mathrm{p}<0.05)$. However, a high significant value of blood glucose level was found in diabetic control chicks as compared to normal control chicks. Hence, our study shows that the hydroalcoholic extract of leaves of Ajuga bracteosa has the antidiabetic potency which reduces the blood glucose level in diabetic chicks.

Copy Right, IJAR, 2017,. All rights reserved.

\section{Introduction:-}

Diabetes mellitus is a group of metabolic diseases characterized by high blood glucose level (World Health Organization, 2014). It results due to the lack of insulin secretion or reduced sensitivity of the tissue to the insulin. Diabetesis recognized as the world's fastest growing chronic condition. The presence of diabetes mellitus confers increased the risk of many devastating complications such as cardiovascular diseases, peripheral vascular diseases (Bajaj and Madan, 1995), complications such as coronary artery diseases, stroke, neuropathy, renal failure, retinopathy amputations and blindness (Nathan, 1996). Diabetes mellitus is one of the leading causes of death in humans and animals. Treatment for diabetes mellitus includes insulin and oral administration of hypoglycemic drugs such as sulfonylureas and biguanides (Tiwari and Madhusudana, 2002).

However, none of these medications is ideal due to toxic side effects and in some cases diminution of response after prolonged use (Dixit and Joshi, 1985). The main disadvantages of the currently available drugs are that they have to be given throughout the life and produce side effects (Eshrat and Abroma, 2003). Although several medicinal plants have gained importance for the treatment of diabetes mellitus, many remain to be scientifically investigated (Punitha et. al., 2006). Many plants reported useful for the treatment of diabetes mellitus in ayurvedic system of medicine have been tested for hypoglycemic activity in experimental animals (Chopra et. al., 1985). 
Ajuga bracteosa is an important Himalayan medicinal plant which belongs to the family Lamiaceae and is commonly known as "Bungle" in English, "Ratpatiya" in Hindi and "Jan-i-adam" in Kashmiri. It is a perennial erect or ascending hairy herb, often prostrate with oblanceolate or sub-spathulate leaves and grows up to 5-50 cm tall. It is distributed in subtropical and temperate regions from Kashmir to Bhutan, Pakistan, Afghanistan, China, Malaysia, western Himalayas, plains of Punjab and upper gangetic plains of India (Khare, 2007) at an altitude of $1300 \mathrm{~m}$. In India, it abounds in western Himalaya at an altitude of $1300 \mathrm{~m}$ (Chandel and Bagai, 2010). It is found along roadsides, open slopes and rock cervices up to $1500 \mathrm{~m}$ above mean sea level (Chauhan, 1999; Upadhyay et. al., 2011).

A large variety of compounds have so far been isolated from Ajuga bracteosa including essential oils, phenolic compounds, flavonoids and tannins. Main components present in essential oil of leaves are limonene, $\alpha$-humulene, $\beta$-myrcene, elemol, camphene, $\beta$-caryophellene, $\alpha$-phellendrene (Vohra et. al., 2011). Different neo-clerodane diterpenoids were isolated from different species of Ajuga (Arfan et. al., 1996; Coll et. al., 2007; Coll and Tandron, 2008; Castor et. al., 2011).

Ajuga bracteosa has important biological activities and acts against different types of diseases. Ajuga bracteosa is used in the treatment of fever, bronchitis, pneumonia, agues, diarrhea, jaundice, rheumatism, gout, palsy and amenorrhoea (Kartikar and Basu, 1918; Manjunath, 1948; Chopra et. al., 1986; Manandhar, 2002; Sharma et. al., 2004, Islam et. al., 2006). It is also used for the treatment of burns boils and syphilis (Johnson, 1999; Sharma et. al., 2004). Ajuga bracteosa contains fiber and antioxidants which play a very important role in controlling diabetes and hypertension (Ziyyat et. al., 1997; Jouad et. al., 2001; El-Hilaly et. al., 2003; Eddouks et. al., 2007; Pawar et. al., 2011).

However, the aim of present study is to check the antidiabetic potency of the hydroalcoholic extract of leaves of Ajuga bracteosa in the form of hypoglycemic value in Alloxan induced diabetic chicks.

\section{Methods:-}

Whole plant of Ajuga bracteosa was collected from the local areas of Lohaghat of Champawat District (Uttarakhand). The leaves were shed dried and coarsely powdered. 500 gm powder of shade dried leaves of the plant were mixed with hydroalcoholic solvent containing $80 \%$ of water and $20 \%$ of alcohol, hot extraction of this mixture was carried out by Soxhlet Apparatus. The extract thus obtained was further freeze dried before use.

Healthy Domestic chicks - Croiler chabra (Gallus gallus domesticus), approximately 2-3 weeks old weighing $100 \pm$ $20 \mathrm{gm}$ of either sex, were selected for the study. Selected all chicks were maintained and acclimatized according to the laboratory conditions of the animal house in the department. The animals were housed in battery cages under laboratory conditions at existing room temperature and relative humidity. They were offered commercial food (Starter, Grower and Finisher) purchased from the market (Godrej Company) and tap water ad libitum. The experimental studies on animal had the prior approval from the Institutional Animal Ethics Committee (IAEC), Department of Pharmaceutical Science, Bhimtal, Kumaun University, Nainital and the member secretary, CPCSEA, Ministry of Environment, Forest and Climate Change, Government of India.

The selected chicks were divided into three groups (A, B and C) randomly, each containing at least 6 chicks. Chicks of group A and B were administered to sub-lethal dose of Alloxan monohydrate (12 mg/100 gm body weight) by intraperitoneally for the induction of diabetes for 7 days daily. The diabetes was confirmed in chicks by estimating blood glucose level by Folin and Wu method (1920) using a commercial kit (Span Biotech, Surat, India). After confirmation of diabetes, chicks of group A were treated as diabetic control and chicks of group B were administered with hydroalcoholic extract of leaves of Ajuga bracteosa (10 mg/100 gm body weight) orally for 30 days daily. Chicks of group $\mathrm{C}$ were administered with saline only to serve as purely control for 30 days.

Group A: Diabetic control (Administered with alloxan - $12 \mathrm{mg} / 100 \mathrm{gm}$ body weight).

Group B: Diabetic chicks treated with hydroalcoholic extract of leaves of Ajuga bracteosa (10 mg/100 gm body weight) 30 days daily.

Group C: Normal control, which receive saline only. 
After 30 days of scheduled treatment all the chicks were starved for 10-12 hours and then were sacrificed by light ether anesthesia in morning hours. Blood was collected through cardiac puncture and blood glucose level was measured by Folin and Wu method (1920) using a commercial kit supplied by Span Biotech (Surat, India).

\section{Statistical analyses:-}

Values are expressed as mean \pm S.E. $(n=3)$. Statistical significance was determined by one way analysis of variance (ANOVA) followed by Dunnet's $t$ test. $\mathrm{P}<0.05$ were considered statistically significant when compared with diabetic control.

\section{Results:-}

Plants are important source of potentially useful structures for the development of new chemotherapeutic agents. The first step towards this goal is physical evaluation of the powered leaves and next is the in vitro anti-diabetic assay. Present work has detected the antidiabetic potency on hypoglycemic activity in alloxan induced diabetic chicks. Hydroalcoholic extract of leaves of Ajuga bracteosa decrease the blood glucose level in diabetic chicks. However, it was found high in diabetic control chicks induced by alloxan.

In experimental protocol diabetes was induced by alloxan in laboratory chicks for a limited period. In these chicks hypoglycemic activity was found high and treated as diabetic chicks. When a group of these chicks was administered with hydroalcoholic extract of leaves of Ajuga bracteosa to check the antidiabetic potency against hypoglycemic activity, the blood glucose level or hypoglycemic activity become reduced in comparison to diabetic control chicks. This hypoglycemic activity was found nearest to normal control chicks. Therefore, our result shows that the Ajuga bracteosa has the potency to protect the diabetes. However, a lot of scientific community has needed to work in this direction. (Table 1).

Table 1:-Antidiabetic potency of leaves of Ajuga bracteosa on hypoglycemic effect in alloxan induced diabetic chicks.

\begin{tabular}{|l|l|l|}
\hline Group & Treatment & Blood glucose level (mg/d) \\
\hline A & Diabetic control & $303.7 \pm 3.48^{*}$ \\
\hline B & Diabetic + Ajuga bracteosa & $287 \pm 1.53 * *$ \\
\hline C & Normal control & $279 \pm 1.2$ \\
\hline
\end{tabular}

1. Results are expressed as mean \pm S.E. $(n=3)$.

2. * Significantly different $(\mathrm{p}<0.05)$ when compared with saline treated control chicks.

3. $* *$ Significantly different $(\mathrm{p}<0.05)$ when compared with diabetic control chicks.

4. Analysis of variance (ANOVA) were significant among all these groups $(29.36, \mathrm{p}<0.05)$.

From the result it may be concluded that the hydroalcoholic extract of Ajuga bracteosa leaves have the potent hypoglycemic effect in alloxan induced diabetic chicks. 


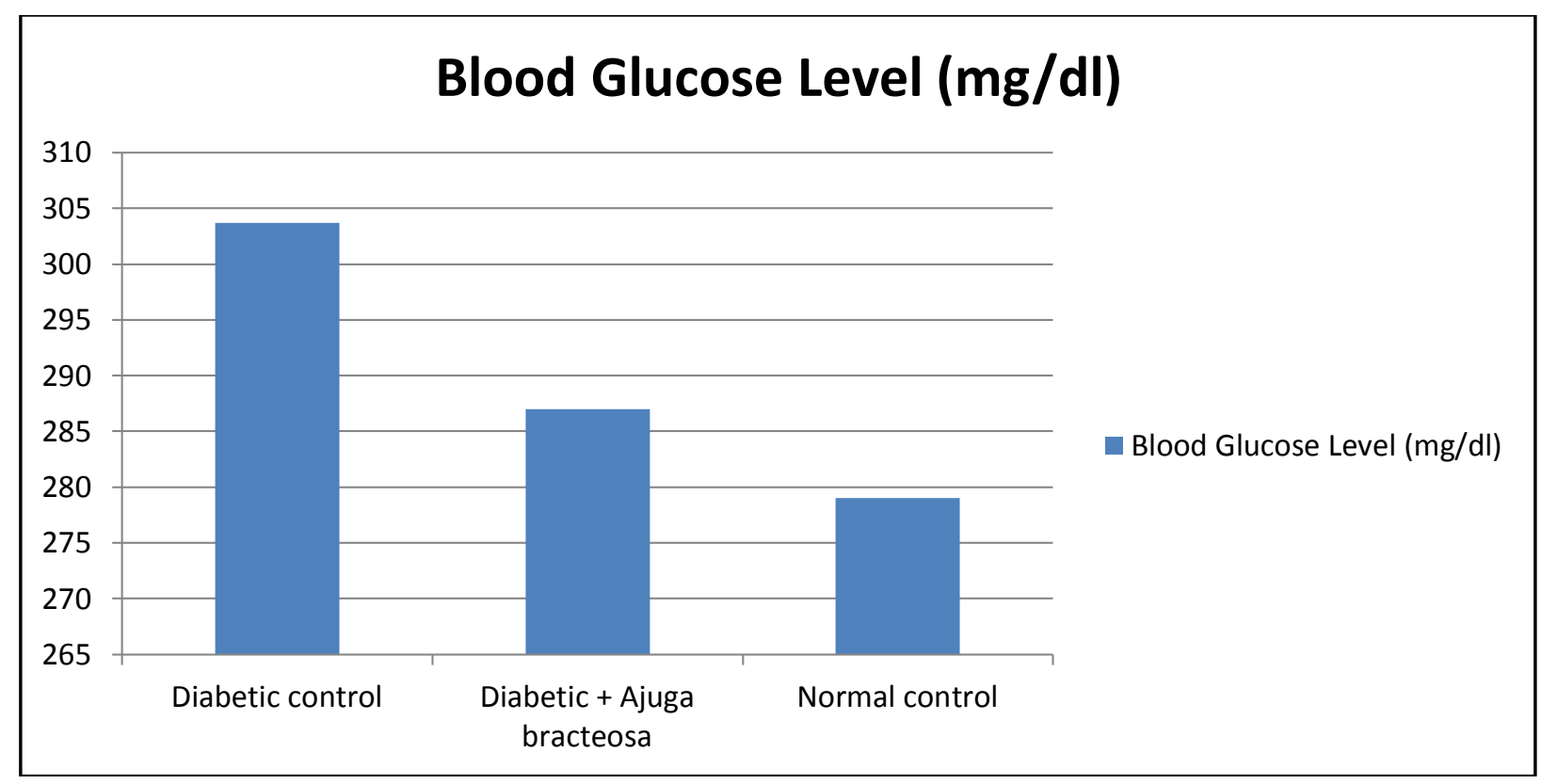

Figure 1:- Antidiabetic effect of leaves of Ajuga bracteosa on hypoglycemic activity in Alloxan induced diabetic chicks.

\section{Discussion:-}

Alloxan ( $\beta$-cytotoxin chemical) induces diabetes in a wide variety of animals including chicks, damages the insulin secreting $\beta$-cells. In the present study, antidiabetic activity of leaves of Ajuga bracteosa was evaluated in the form of hypoglycemic activity in Alloxan induced diabetic chicks. The present result reveals that blood glucose level was reduced in diabetic control chicks treated with hydroalcoholic extract of leaves of Ajuga bracteosa in comparison to diabetic control chicks. Blood glucose level was depressed by $\%(\mathrm{p}<0.05)$ in alloxan induced diabetic chicks after treatment which was comparable to the normal saline feed chicks (Table 1). This may be due to the activation of the existing pancreatic cells in diabetic chicks by the hydroalcoholic extract.

The aim of the present study is an attempt to investigate out the phytochemical and ethnopharmacological application of Ajuga bracteosa wall benth, to treat diabetes mellitus in domestic chicks (Gallus gallus domesticus). In North, Ajuga plants are used to treat diabetes and hypertension (Ziyyat et. al., 1997; Jouad et. al., 2001; Bnouham et. al., 2002; El-Hilaly and Lyoussi, 2002; Eddouks et. al., 2002; El-Hilaly et. al., 2003; Tahraoui et. al., 2006; Eddouks et. al., 2007), as a panacea (cure-all) (Hassar, 1999), specifically for gastrointestinal disorders (Baytop, 1984; Bellakhdar et. al., 1991). Diabetes mellitus is a chronic disorder caused by partial or complete insulin deficiency which produces inadequate glucose control and leads to acute and chronic complications. Diabetes mellitus is considered as one of the five leading cause of death in the world (Vats et. al., 2004).

Alloxan (2, 4, 5, 6-tetraoxypyrimidine; 2, 4, 5, 6-pyrimidinetetron) is an oxygenated pyrimidine derivative (Lenzen, 2008). Alloxan is a toxic glucose analogue, when administered to rats and many other species which selectively destroys insulin producing $\beta$-cells in the pancreas resulting in insulin dependent diabetes mellitus (Alloxan Diabetes) with characteristics similar to type 1 diabetes in humans (Lenzen, 2008). Present result shows that alloxan induced diabetes in group A in comparison to normal control chicks. This followed by group B in which Ajugabracteosa is used as an antidiabetic therapy and gradually decreases the hypoglycemic activity in these chicks.

The study reveals that the hydroalcoholic extract of leaves of Ajuga bracteosa exhibited significant antihyperglycemic activity in alloxan induced diabetic chicks. Fasting blood glucose level in alloxan induced diabetic chicks is an important basal parameter for monitoring diabetes (Maiti et. al., 2005). The significant decrease in the level of level of fasting blood glucose in diabetic chicks treated with the hydroalcoholic extract of leaves of Ajuga bracteosa may be by the stimulation of the residual pancreatic mechanism, probably by increasing peripheral utilization of glucose. These results support the study conducted by the Erah et. al. (1996). 
The herb contains comparatively larger amounts of chromium (leaves $25 \mathrm{mg}$ and roots $20 \mathrm{mg}$ per $100 \mathrm{~g}$ ) which may be correlated to its use as remedy for diabetes as per Ahmed et. al., Chromium is another essential mineral that human require in trace amounts. It is an important component of many body building strategies to and in the development of lean muscle mass, as well as in the treatment of diabetes and for weight loss. Chromium increases the metabolism of proteins, fats and carbohydrates. Significantly, it enhances the efficiency of insulin to regulate blood sugar levels (Anderson et. al., 1983; Bunker et. al., 1985; Sealy and Laragh, 1995).

The antihyperglycemic activity of the hydroalcoholic extract of leaves of Ajuga bracteosa was due to the regeneration of pancreatic cells that were partially destroyed by alloxan and potentiation of langerhans (Suba et. al., 2004). The hydroalcoholic extract of leaves of Ajuga bracteosa may increase secretion of insulin from $\beta$-cells of pancreas and results in of this increased secretion of insulin stimulate fatty acid biosynthesis and also the incorporation of fatty acids into triglycerides in the liver and adipose tissue (Best and Taylor, 1989).

\section{References:-}

1. "About diabetes": World Health Organization. Retrieved 4 April 2014.

2. Anderson. R.A., Polansky. M.M., Bryden. N.A., Patterson. K.Y., Veillon. C. and Glinsmann. W.H., (1983). J Nutr., 113: 276-81.

3. Arfan. M., Khan. G.A. and Ahmad. N., (1996). Steroids and terpenoids of the genus Ajuga.Journal of Chemical Society of Pakista., 18: 170-174.

4. Bajaj. J.S., Madan. R., (1995). Diabetes in tropics and developing countries., 38(2): 5-6.

5. Baytop. T., (1984). Therapy with Medicinal Plants (Past and Present); Istanbul University Publications, Istanbul, pp.298, 416.

6. Bellakhdar. J., Claisse. R., Fleurentin. J. and Younos. C., (1991). Repertory of standard herbal drugs in the Moroccan pharmacopoeia. J. Ethnopharmacol., 35: 123-143.

7. Best. C.H. and Taylor. N.B., (1989). Biological effect of Insulin. In: Physiological Basis of Medical Practice, Wilkins. W.W., (Ed.). Cambridge University Press, London.

8. Bnouham. M., Mekhfi. H., Legssyer. A. and Ziyyat. A., (2002). Medicinal plants used in the treatment of diabetes in Morocco. Int. J. Diabetes Metab., 10: 33-50.

9. Bunker. V.W., Lawson. M.S., Delves. H.T. and Clayton. B.E., (1985). Am J Clin Nutr., 39: 797-802.

10. Castro. A., Coll. J. and Arfan. M., (2011). Neo-Clerodanediterpenoids from Ajugabracteosa - Journal of natural products 5:1036-41.

11. Chandel, S., Bagai, U., (2010). Antiplasmodial activity of Ajugabracteosa against Plasmodium berghei infected $\mathrm{BALB} / \mathrm{c}$ mice Indian journal of medicinal research 131: 440-444.

12. Chauhan. N.S., (1999). Medicinal and aromatic plants of himachal Pradesh Indus publishing company New Delhi.

13. Chopra. R.N., Chopra. I.L., Honda. K.L. and Kapur. L.D., (1958). Indigenous Drugs of India. 2nd ed. Calcutta: U.N. Dhar and Sons Ltd., p. 300-29.

14. Chopra. R.N., Nayar. S.L. and Chopra. I.C., (1986). Glossary of Indian Medicinal Plants (Including the Supplement). Council of Scientific and Industrial Research, New Delhi, pp.330.

15. Coll. J. and Tandron. Y.A., (2008). Neo-clerodanediterpenoids from Ajuga. Structural elucidation and biological activity. PhytochemistryReviews.,7: 25-49. International Journal of Advanced Research., 2014; Volume 2: Issue 1: 389-394 392.

16. Coll. J., Tandron. Y.A. and Zeng. X.N., (2007). New phytoecdysteroids from cultured plants of AjuganipponensisMakino. Steroids.,72: 270-277.

17. Dixit. V.P. and Joshi. S.C., (1985). Antiatherosclerotic effects of alfalfa meal ingestion in chicks: A biochemical evaluation. Indian J PhysiolPharmacol., 29(1): 47-50.

18. Eddouks. M., Maghrani. M., Lemhadri. A., Ouahidi. M.L. and Jouad. H., (2002). Ethnopharmacological survey of medicinal plants used for the treatment of diabetes mellitus, hypertension and cardiac diseases in the southeast region of Morocco (Tafilalet). J. Ethnopharmacol., 82: 97-103.

19. Eddouks. M., Ouahidi. M.L., Farid. O., Moufid. A., Khalidi. A. and Lemhadri. A., (2007). The use of medicinal plants in the treatment of diabetes in Morocco. Phytotherapie., 5: 194-203.

20. El-Hilaly. J. and Lyoussi. B., (2002). Hypoglycaemic effect of the lyophilised aqueous extract of Ajugaiva in normal and streptozotocin induced diabetic rats. J. Ethnopharmacol., 80: 109-113.

21. El-Hilaly. J., Hmamouchi. M. and Lyoussi. B., (2003). Ethnobotanical studies and economic evaluation of medicinal plants in Taounate province (Northern Morocco). Journal of Ethnopharmacology., 86: 149-158. 
22. Erah, P.O., Osuide. G.E. and Omogbai. E.K.I.,(1996). Hypoglycemic effect of the extract of Solenostemonmonostachys leaves. J. WestbAfr. Pharma., 10: 21-27.

23. Eshrat. M.H., (2003). Effect of Cocciniaindica (L.) and Abromaaugusta (L.) on glycemia, lipid profile and on indicators of end-organ damage in streptozotocin induced diabetic rats. Indian J ClinBiochem., 18(2): 54-63.

24. Folin. O. and Wu. H.J., (1920). Biol. Chim., XII, 367.

25. Hassar. M., (1999). La phytothérapie au Maroc. EspéranceMédicale, 47: 83-85.

26. Islam. M., Ahmad. H., Rashid. A., Razzaq. A., Akhtar. N. and Khan. I., (2006). Weeds and medicinal plants of Shawar valley, district Swat. Pakistan Journal of Weed Science Research., 12: 83-88.

27. Jouad. H., Haloui. M., Rhiouani. H., El-Hilaly. J. and Eddouks. M., (2001). Ethnobotanical survey of medicinal plants used for the treatment of diabetes, cardiac and renal diseases in the north centre region of Morocco Journal of Ethnopharmacology., 77: 175- 182.

28. Khare. C.P., (2007). Indian Medicinal Plants - An Illustrated Dictionary. 1st Indian Reprint Springer (India) Pvt. Ltd., New Delhi, India: 28., International Journal of Advanced Research., 2014; Volume 2, Issue 1, $389-394$.

29. Kirtikar. K.R., Basu. B.D., (1918). Indian Medicinal Plants. Indian Press, Allahabad.

30. Lenzen. S., (2008). The mechanism of alloxan and streptozotocin induced diabetes. Dibetologica., 51: $216-226$.

31. Maiti. R., das. U.K. and Ghosh. D., (2005). Attenuation of hyperglycemia and hyperlipidemia in streptozotocin induced diabetic rats by aqueous extract of seed of Tamarindusindica. Biol. Pharm. Bull., 28: 1172-1176.

32. Manandhar. N.P., (2002). Plants and People of Nepal. Timber Press, Oregon, pp.636.

33. Manjunath. B.L., (1948). The Wealth of India, Vol. 1, Delhi: Council of Scientific and Industrial Research., p.254.

34. Nathan D.M., (1996) The pathophysiology of diabetic complications: How much does the glucose hypothesis explain? Ann Intern Med., 124: 86-9.

35. Pawar. R.S., Pal. A., Jadon. M., Katare. Y.K., Singour. P.K., Rajak. H. and Patil. U.K., (2011). Ajugabracteosa A review on its ethnopharmacological and phytochemical studies, Der pharmaciasinica., 2:1-10 .

36. Punitha. R., Vasudevan. K. and Manoharan. S., (2006). Effect of Pogamiapinnata flowers on blood glucose and oxidative stress in alloxan induced diabetic rats. Indian J Pharmacol., 38(1): 62-3.

37. Sealy. J.E. and Laragh. J.H., (1995). The rennin-angiotensin-aldosterone system for normal regulation of b.p. and sodium and potassium homoestasis. In: Laragh. J.H. and Brenner. B.M., editors. Hypertension: Pathophysiology, diagnosis and management, Raven press: New York., 2.

38. Sharma. P., Mohan. L. and Srivastava. C.N., (2004). Larval susceptibility of Ajugaremota against anopheline and culicine mosquitos. Southeast Asian Journal of Tropical Medicine and Public Health 35: 608-610.

39. Suba. V., Murugesan. T., Rao. R.B., Ghosh. L., Pal. M., Mandal. S.C. and Saha. B.P., (2004). Antidiabetic potential of barlerialupulina extract in rats. Fitoterapia., 75: 1-4.

40. Tahraoui. A., El-Hilaly. J., Israili. Z.H. and Lyoussi. B., (2007). Ethnopharmacological survey of plants used in the traditional treatment of hypertension and diabetes in south-eastern Morocco (Errachidia province). J. Ethnopharmacol., 110: 105-117.

41. Tiwari. A.K. and Madhusudana. Rao., (2002). Diabetes mellitus and multiple therapeutics approaches of phytochemicals: present status and future prospects. Curr. Sci., 83: 30-38.

42. Upadhyay. S.U., Patel. V.B., Patel. A.A., Upadhyay. U.L. and Patel. N.M., (2011). Ajugabracteosa- A promising herb Pharma science monitor - An international journal of pharmaceutical sciences., 20: 80-88.

43. Vats. V., Yadav. S.P. and Grover. J.K., (2004). Ethanolic extract of Ocimum sanctum leaves partially attenuates streptozotocin induced alterations in glycogen content and carbohydrate metabolism in rats. J. Ethnopharmacol., 90: $155-160$.

44. Vohra. A. and Kaur. H., (2011). Chemical investigation of Medicinal plant Ajugabracteosa. Journal of natural product and plant resource., 1: 37-45. International Journal of Advanced Research., (2014); Volume 2, Issue 1, 389-394.

45. Ziyyat. A., Legssyer. A., Mekhfi. H., Dassouli. A., Serhrouchni. M. and Benjelloun. W., (1977). Phytotherapy of hypertension and diabetes in Oriental Morocco. Journal of Ethnopharmacology., 58: 45-54. 